\title{
$\mathrm{Ni}-\mathrm{Sn}$ 合金の時効硬化についで
}

\author{
三島德七苂 橋口隆 吉** 木 村 康夫**
}

Tokushichi Mishima, Ryukiti Hasiguti and Yasuo Kimura: Age-Hardening of Nickel-Tin Alloys. The age-hardening process of nickel-14 16\% tin alloys was studied. The spesimens were quenched in water and aged at $550 \sim 625^{\circ}$ for various lengths of time. Their magnetic properties, Vickers hardness, lattice parameter and microscopic structure were observed during the age-hardening process. The behaviors of the intensity of magnetization temperature curves and the changes of the lattice parameter give evidences for discontinuous precipitation. The fractional changes of the coercive force and the Vickers hardness are identical with each other at respective aging temperatures except in the early stage of aging. The changes of properties can be described by the Austin-Rickett equation; $p /(1-p)=k t^{n}$. The activation energy of the aging process in this alloy is $33,000 \mathrm{cal} / \mathrm{mol}$.

(Received February 22, 1956)

\section{I. 緒霎}

我及はさきに Fe-Mo合金の時効に伴ら抗磁力と機栈的 硬さとの間には，一次的な關婇がないことを發表した(1)(2) (3). 今回は强磁性 $\mathrm{Ni}-\mathrm{Sn}$ 合金の時効過程中に怙ける磁氣 的性質扔よで機械的硬さなどを測定し、さらにそれらの相 互關係扣よで析出の舉㡖について研究した. ニッケル合金 の㭙効過程を磁氣的に調べるには, $\mathrm{Ni}-\mathrm{Au}$ 系, $\mathrm{Ni}-\mathrm{Be}$ 采招 よび N1-Sn 系が望丈しいが，材料入手の關係から $\mathrm{Ni}-\mathrm{Sn}$ 合金を周いることにした．時効により Ni-Sn 合金の過飽 和固溶踖から $\mathrm{Ni}_{3} \mathrm{Sn}$ 相が析出寸る(4).この合金の特效硬化 に關する研究は Fetz と Jett€(5) がうัnをそれぞれ 20,

** 東京大學工學部治金學教窒

* 1951 年 4 月本會東京大會に殿表.

(1) 三島，橋口，木村，本誌， 20 (1956)，165

(2) 三島, 橋口, 木村, 本誌, 20 (1956), 169.

(3) 木村, 橋口, 金屬物理, 2 (1956), 27.

(4) Metals Handbook(1948)ASMによると850〜890 に $\beta$ 相と $\beta^{\prime}$ 相 $\left(\mathrm{Ni}_{3} \mathrm{Sn}\right)$ の變態點がある.

(5) E. R. Jette and E. Fetz, Metallwirtschaft, 14 (1935), 165.
15,10 抢よび $5 \mathrm{wt} \%$ 含む $\mathrm{Ni}-\mathrm{Sn}$ 合金を $500 \sim 600^{\circ}$ で時効 したときのブリネル硬さを測定したのがあるのみで，磁氣 的に測定した報告はないようである.

\section{II. 草 驩 方 法}

電解ニッケルと純錫を用いて $\mathrm{Ni}-16 \% \mathrm{Sn}$ 括よび $14 \%$ $\mathrm{Sn}$ 合金 2 種類を高周波爐で熔解した.な招脫酸劑として少 量の $\mathrm{Mn}$ 招よび $\mathrm{Al}$ を用いた. $1130^{\circ}$ で $4 \mathrm{hr}$ 加熱後水燒入 後時効した. 磁性測定周試片は俓 $5 \mathrm{~mm}$, 長さ $80 \mathrm{~mm}$ の試 驗片を周いた．前回と同じく抗磁力は磁力計を用いて，鵤 和磁化の强さは磁束計を用いて測定した. また初帶磁率の 測定には彈動ガルバ法を用いて測定した，硬さはビッカー ス硬变計で荷重は $20 \mathrm{~kg}$ を用いた. マトリックスの格子常 數は銅の $\mathrm{K}_{a}$ 線を用いて測定した.

\section{III. 實 穱 結 果}

$1130^{\circ}$ で $4 \mathrm{hr}$ 加熱後水燒入れ し, $\mathrm{Ni}-16 \% \mathrm{Sn}$ 合金は $600^{\circ}$ で, Ni-14\% Sn 合金は $625^{\circ}$ でそれぞれ時効し，機

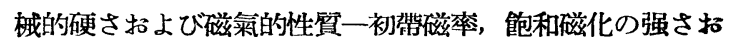


よび抗磁力一を測定した. $\mathrm{Ni}-16 \% \mathrm{Sn}$ 合金を $600^{\circ}$ で時効 した結果を Fig. 1 に示した. 末た Ni-14\% Sn 合金を $625^{\circ}$ で時効した結果を Fig. 2 に示した. それらの值は異なる が顿向は同樣である．抗磁力，飽和磁化の强さは時効時間 と共に徐々に上昇し，次第にその變化速度を增加し，逐に 最大值に達する.これに反して初帶磁率は時効時間と共に 徐ふに減少し，炽第に變化速度を增加し遂に一定值に近ず $<$.

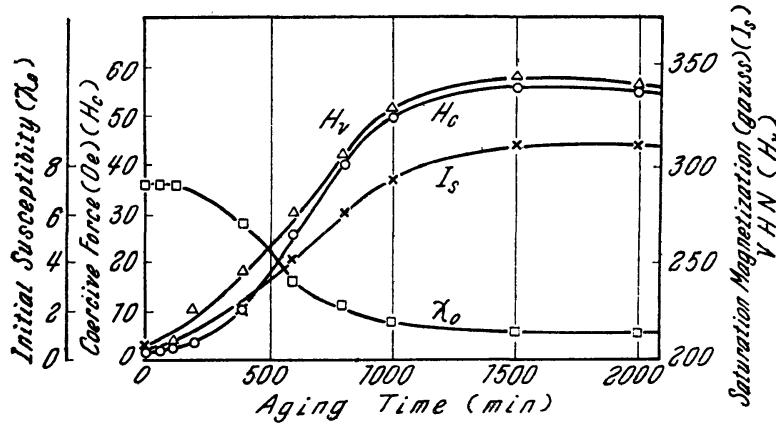

Fig. 1 Magnetic properties and mechanical hardness of $\mathrm{Ni}-16 \% \mathrm{Sn}$ alloy aged at $600^{\circ}$.

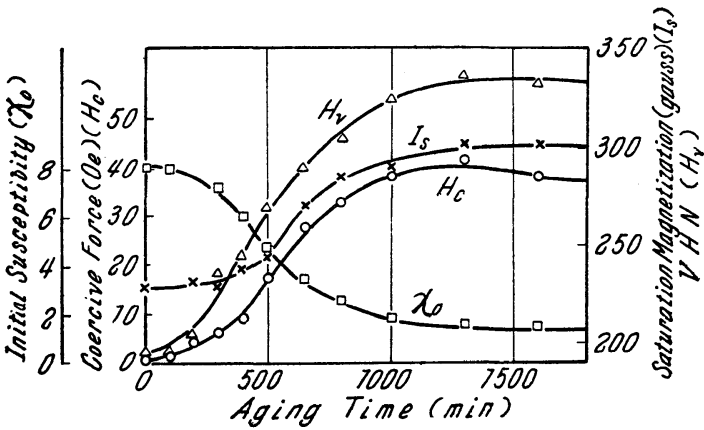

Fig. 2 Magnetic properties and mechanical hardness of $\mathrm{Ni}-14 \% \mathrm{Sn}$ alloy aged at $625^{\circ}$.

硬さは時効と共に上算し，逐に一定値になり抗磁力と同 ビよらな樂化を示す.

\section{IV. 析出 の機構}

合金の析出の機構として，連續析出と不連續析出とがあ る. Ni-16\% Sn 合金がどちらの機構により析出するかを 磁氣分析，格于常數の變化怙よび顯微鏡組織により調べた

\section{1. 磁軹分析}

$600^{\circ}$ に種々の特間時效した $\mathrm{Ni}-16 \% \mathrm{Sn}$ 合金を $600 \mathrm{Oe}$ 磁場中で $300^{\circ}$ まで加熱括よび邻却し磁氣分析をした，時効 時間を繨えて磁化の强さ $I$ と溫度 $T$ との關係を調べた. 時 効与ると固溶體の $\mathrm{Sn}$ 濃窅は減じ，キュリ一點が上昇して くる. 過飽和固溶體についての磁氣の强さ $I$ と溫度 $T$ との 關係は，强磁性單相に招けるものと同樣な $I-T$ 曲線を示 ナ. 燒入れたときのキュリー點は $70^{\circ}$ 位であるが, 燒入れ たま〉の試片でも高溫側に $100^{\circ}$ 附近まで尾を引く，時効 ナると $\mathrm{Ni}_{3} \mathrm{Sn}$ 相が析出してきてマトリックスの濃度は $\mathrm{Sn}$ が低くなり $\mathrm{Ni}_{3} \mathrm{Sn}$ 相と本衡する溶解度の組成に相當する 縟安になる，その濃度は $600^{\circ}$ の時效では約 $2 \mathrm{at} \% \mathrm{Sn}(4 \mathrm{wt}$
\% Sn）に相當する.この 2 at％ Snの相のキュリー嘿は $280^{\circ}$ 附近にある. 强磁性相は析出完了した約 2 at $\% \mathrm{Sn}$ を 含七新相と過飽和固溶體の古相の 2 相である. 析出が逜續 析出であるとキュリー默抢よび磁化の强さは運續的に上昇 し，單一强磁性體の $I-T$ 曲線を示方はずである。 しかし この合金を種々の時間時效したときの $I-T$ 帕踪を求める と Fig. 3 のよらに二つの曲線の重䁷した曲䋨がえられる. たとえば $600^{\circ}$ で $600 \mathrm{~min}$ 赫効させたときには約 $90^{\circ} に キ$

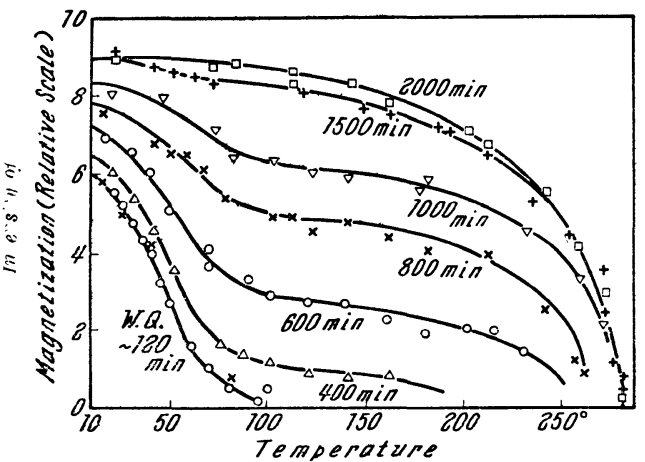

Fig. 3 Intensity of magnetization temperature curves of $\mathrm{Ni}-16 \% \mathrm{Sn}$ alloys aged for various lengths oi time at $600^{\circ}$.

ュリー點を有する相と $280^{\circ}$ 附近にキュリ一點を有する相 の二つの曲線を重䁷した曲線がえられた*. 過飽和固溶體の キュリー點は殆ど變化しないが，時效初期では少しずつ高 溫の方へずれているよらである.析出が起るに從い過飽和 固溶體の體積减少により磁化の强さが減少する。これに反 して $\mathrm{Ni}_{3} \mathrm{Sn}$ 相を析出した殘りの $280^{\circ}$ 附近にキュリ一哭を 有する相の磁化の强さの增加が元の過飽和固溶體の減少に

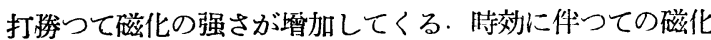
の强さ $I$ と溫度 $T$ との曲絈が Fig. 3 のような擧唾を示す のは Ni-16\% Sn 合金の析出機構として不連續析出か涯倒 的に優勢であることを表わしている。

\section{3. 格子常數の變化}

$\mathrm{Ni}-16 \% \mathrm{Sn}$ 合金を $1,130^{\circ}$ から水燒入れした京〉では格 于常數 $3.592 \AA$ であるが $600^{\circ}$ で $200 \mathrm{~min}$ 時効すると過 饱和固溶體の格厅常数の他に $3.544 \AA$ の新相が現われ始め $400 \mathrm{~min}$ 間時效では過飽和固溶體が未げ殘つている。 さら

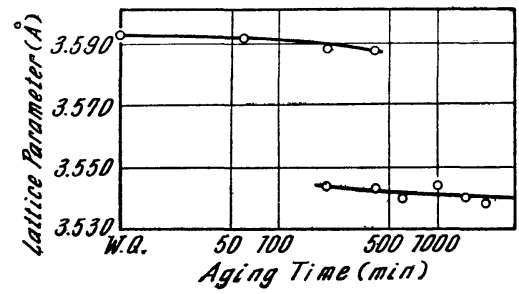

Fig. 4 Lattice parameter of $\mathrm{Ni}$ $16 \% \mathrm{Sn}$ alloys aged at $600^{\circ}$. に時効すると 始めの過飽和 固溶體からの 線は見えず， 新相の格于常 僌は徐々に減 少する. しか ᄂ $2000 \mathrm{~min}$ 間時效すると

露が非常に大きくなるので，線が非常にぼけてくるが大體

* このよらにキューリー點の塂なる 2 相から成立つて いることは比熱の測定によりても確められた 
3.538 A となる. Fig. 4 のよらにマトリックスの格子常數 は連續的に變化せず，磁氣分析から期待されるよらに不連 續析出を示している.

\section{3. 顆微鏡組織の變化}

$\mathrm{Ni}-16 \% \mathrm{Sn}$ 合金を $1130^{\circ}$ より水塱人したょっでは, 一相 で双昆が見えているが, $600^{\circ}$ で $200 \mathrm{~min}$ 間時効与ると粒界 に僅かながら析出してくる.この場合よく析出する粒界と 出難い粒界とがある．これは隣合つた結晶粒相互の方向に よるのであろら，双晶關係にある粒界には全然析出してい ない. $400 \mathrm{~min}$ 特効すると Fig 5のよらにそのウが益て增 大して塊狀に粒界に析出する.ささらに時效すると結晶粒内

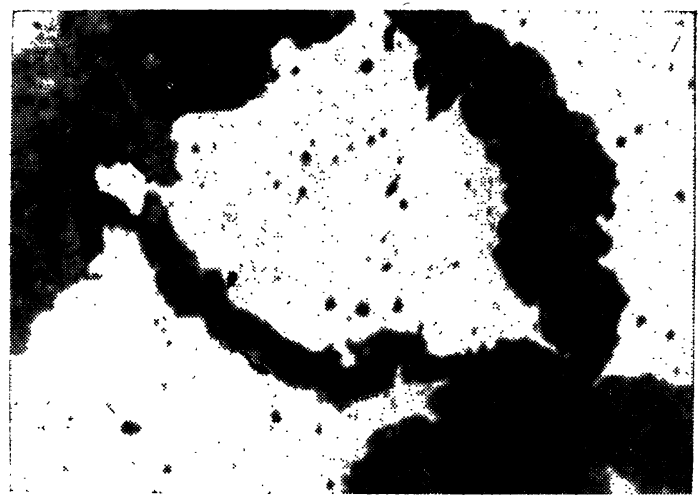

Fig 5 Discontinuous precipitation starting from grain boundaries in $\mathrm{Ni}-16 \% \mathrm{Sn}$ alloy aged $400 \mathrm{~min}$ at $600^{\circ}$.

部にも析出してきて最後には全闻的に析出する. その後再 結昆を件ららしく，結晶粒が微細化される傾向がある。

$\mathrm{Ni}-11.3$ at\% 扔よび 50 at\% $\mathrm{Au}$ 合金を時効したときに は不連續析出が優势であり(5)(7)，末た Ni-2.5 at\% Be合金 を $454^{\circ}$ で時効したと劣には連絸析出であつた(7). Ni-16\% Sn 合金を $600^{\circ}$ に時効したとさには, 磁氯分析, 格子常數 の継化拉よび顯微鏡組織により不連續析出が優禁であるこ とがわかつた

\section{V. 封効による硬さ變化と活性化エネルギー}

前笛で肬べたように，結昆粒界から析出が進むために結 晶粒の大きさにより時效硬化速度が變化する. 比較のため には同一熱履歷を受けた結晶粒の揃つた試驗片について測 定しなければならない. $1130^{\circ}$ から水埜入し，550，575， 600 拈よび $625^{\circ}$ の各一定溫要で時効させたとき，時効に伴 らビッカース硬さの變化を Fig. 6 に示した.

時效初期には停涩しているが徐队に變化速度を增し, 曲 線が立つてきて, 最高值に達し次いで硬さが幾分低下して くる.時効溫度が高い汪ど，硬さの最高值が低下している のは $\mathrm{Ni}$ に對する $\mathrm{Sn}$ の溶解度が時效溫度範園で異なつて いることが一つの原因となつでいるであろう．

前報(1)(2)に示したよらに燒入れたときのビッカース硬さ

(6) W. Köster u. W. Dannähl, Z. Metallk., 28(1936), 248.

(7) W. Gerlach, Z. Metallk., 29 (1937), 102.

の値を $H_{\theta}$ ，飽和になつたときのそれを $H_{s}$, 時間 $t$ にっけ る値を $H$ とす机ば, 變化率 $p$ を

$$
p=\left(H-H_{0}\right) /\left(H_{s}-H_{0}\right)
$$

で定義することが出來る.この變化率 $p$ を用いて

$$
p /(1-p)=k t^{n}
$$

が Austin-Rickett の式を示す.こつで $k$ とは常數で

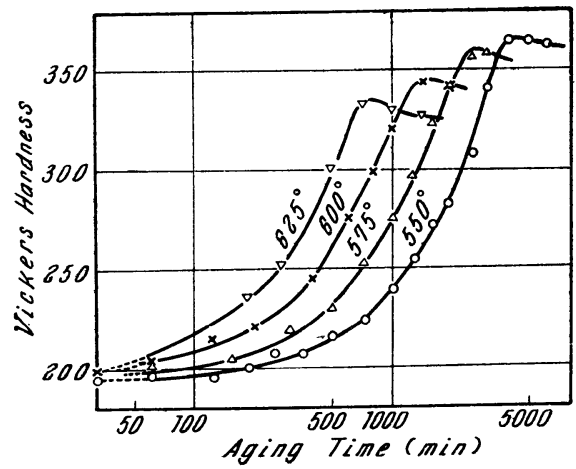

Fig 6 Vickers hardness versus aging time at various aging temperatures.

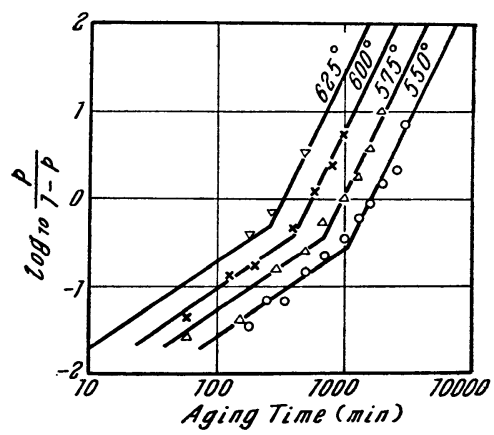

Fig. 7 Fractional changes, $p$, of Vickers hardness as a function of aging time, $t$, at various aging temperatures.

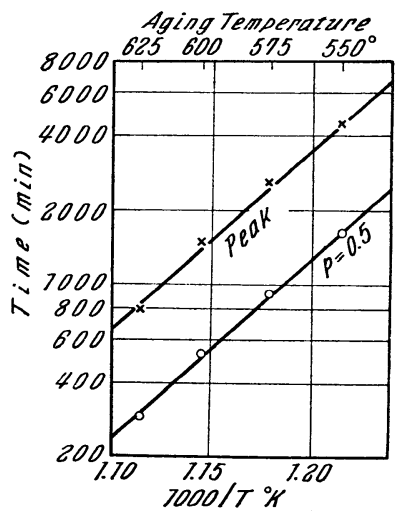

Fig. 8 Logarithms of the time to two stages of $\mathrm{Ni}-16 \% \mathrm{Sn}$ alloy as a function of reciprocals of absolute temperatures, $T$, of aging.

ある・(2) 式の對數 をとり ビッカー ス硬さの 變化率 $p$ をプロッ トすると Fig. 7 の よらにな る. 變化 率 $p=0.3$ 附近で傾斜の 異なる 2 本の 值線が交わ る. 線の傾斜 から (2) 式の $n$ が求められ る. $n$ の值は 溫度によらず 一定で，傾斜 の急な方が $n=3$, 緩かな 方が $n=1$ と なる。

$\mathrm{Fe}-\mathrm{Mo}$ 合金のとき には $20 \%$ Mo 合金て $n=4^{(1)}, 15 \%$ Mo 全金 で $n=3^{(2)}$ であつた. 本 合金も析出硬化型合金 であるために $n=3$ に なつたのであろら。時 效初期に $n=1$ になつ たのは擬安定相が析出 したためかも知れない が明らかでない(8).

最高の硬さがえられ るまでの時効時間を $t_{\text {peak }}$ とし, 最高值の 牛分だけ變化するのに 要する時間を $t_{0} 5$ とする. 縱軸的時効時間の對數，橫軸に

(8) 三島, 大日方, 橋口, 本 誌, 12(1948), No. 7-12, 16. 
時効溫度 (絕對溫度) の逆數をとつたグラフに各時效溫度 おける $t_{\text {peak }}$ 㧊よび $t_{0.5}$ の值をプロットすると Fig. 8 の よらに直線的虍係があり， $t_{\text {peak }}$ と $t_{0.5}$ 共にその直繶の傾 科が等しく，

$$
t=t_{0} \exp \left(\frac{33,000}{R T}\right)
$$

となる $\mathrm{Ni}-16 \% \mathrm{Sn}$ 合金の時效硬化の 活性化ェネルギー は $33,000 \mathrm{cal} / \mathrm{mol}$ となる

\section{VI. 抗磁カと機械的硬さの闒係}

$\mathrm{Ni}-16 \% \mathrm{Sn}$ 合金特よび Ni-14\% Sn 合金を特効したと きの抗磁力と機栈的硬さについて (1) 式で定義さ扎た變化 率をとると Fig 9のよらに大體比例的關係がある.このよ

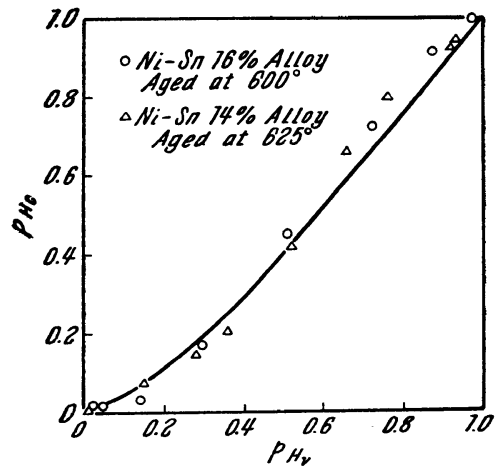

Fig. 9 Relationship between fractional change of coercive force and that of Vickers hardness.
らな關係のない $\mathrm{Fe}-\mathrm{Mo}$ 合金 ${ }^{(3)}$ と比較して興味 のあることであ る. 變化率が小 さいところで は, 兩方の差が 大さいが析出が 進むと大體一致 ナる. 㯁憵力 の大きさ $z$ とそ の分布が抗磁力 を决定するとい ๖ Beckerの理

碖によれば, 抗磁力 Hcは次式により示される.

$$
H c=\frac{3}{2} p^{\prime} \frac{\lambda z}{I_{S}}
$$

こっで $\lambda$ は飽和磁歪，Is は飽和磁化の强さ， $p^{\prime}$ は队部應 力の分布に關係のある係數である. $\lambda /$ Is が時効により殆ど 變化しなければ，抗磁力 $\mathrm{Hc}$ は $p^{\prime} z$ に比例する．機械的硬 さもやはり內部應力によると考えられるから抗磁力と比例 ナるであろら． $p^{\prime}$ は磁壁の厚さ $\delta$ と內部應力の波長 $l$ の函

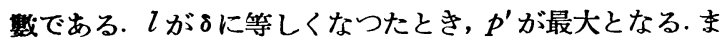
た Becker によればр'は矢式により與えられる.

$$
p^{\prime}=\frac{3 H c \chi_{0}}{I_{S}}
$$

抗磁力 $\mathrm{Hc}$, 初帶磁率 $\chi_{0}$, 飽和磁化の强さIs が測定されて いるから上式から內部應力の分布に關係のある係椠: $p^{\prime}$ を 算出すると Fig. 10 のよらにある時効時間に最大値のある 曲線がえられる。

最近, 內部應力が不規則的に分布しているときの材料の

(9) R. Becker, Proc. Phys. Soc., 52 (1940), 138.

抗磁力の一般式を Néel(10) が與えた. そこで磁氣異方性常 婁 $K \ll \frac{3}{2} \lambda z$ のときの抗磁力は

$$
H c \approx 0.69 \frac{v^{\prime}}{I s} \cdot \frac{3}{2} \lambda z\left[1.386+\log _{e} \sqrt{\frac{6.8 I s^{2}}{\frac{3}{2} \lambda z}}\right]
$$

で與えられている.こっで $v^{\prime}$ は焦力分布に關係する俰數で

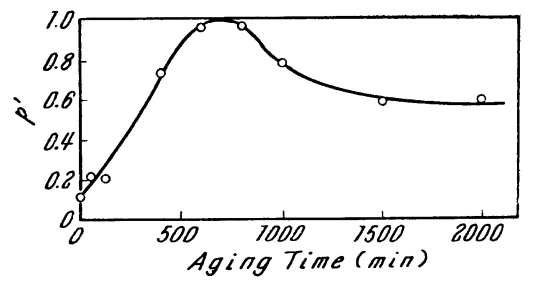

Fig. 10 The factor, $p^{\prime}$, which depends on stress distribution, as a function of aging time at $600^{\circ}$.
おる. Beciker の理誏と比較 すると $3 / 2 \lambda z$ が $10^{5}$ dynes/ $\mathrm{cm}^{2}$ 以上では Neél の理論 の(6)式の $H c$ $/ v^{\prime}$ とBecker 理䣐の (4) 式 の $H c / p^{\prime}$ とは大體一致するが, その值以下では差は大きく なる. そこで本材料に對しては磁歪も測定されて扣らず, $z$ の值む明らかでないので正確な比較はできないが, Becker の理論を㬨ててその傾向のみは正しいと思われ る.

\section{VII. 總括}

$\mathrm{Ni}-14 \% \mathrm{Sn}$ および Ni-16\% Sn 合金を $1,130^{\circ}$ に加熱後

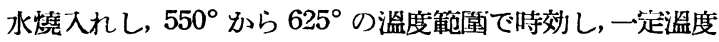
に招ける時効時間に件ら磁性, ビッカース硬さ, 格う常辒: 括よび顯微鏡組織の變化を測定した，その結果を總括する と,

(1) 磁化の强さ-溫曼曲圝: マトリックスの格厅常嘍の變 化扣よび顯微鏡組織から析出機構:として不連續析出が優勢 であることがわかつた。

(2) 時效によるビッカース硬さの變化率は Austin Rickett の (2) 式にあてはまり, 時効の初期では $n=1$, 變化率 $p$ が 0.3 より大きくなると $n=3$ となる.

(3) 時效硬化の活性化エネルギーとして 33,000心 $1 / \mathrm{mol}$ がえられた。

(4) 時效に伴ら抗磁力拉よびビッカース硬さの戀化率は 時効の初期では少しはずれるが，析出が進むに從い，よく 一致する.

(5) Becker 理論よりえられた (4) 式の 户谙㣹力分布に

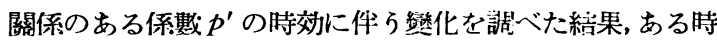
效時間後に最大值をもつ曲線が忩られた。

終りに臨み本研究に關して有湓な討椧をして下さつた研 究室の諸兄に感謝の意を表する次第である。

(10) L. Néel, Physica, 15 (1949), ¿25. 